\title{
Role of Protein-Based Food (PBF) in Combating Undernutrition; Milk and Eggs as an Example
}

Ihab Naser*

Program of Clinical Nutrition, Faculty of Pharmacy, Al Azhar University, Gaza Strip, Palestine

\begin{abstract}
Provision of Protein-Based Food remains an important strategy for the prevention and treatment of malnutrition and can produce substantial improvements in the functional performance of malnourished individuals and populations. Many potential benefits of Protein-Based Food require further exploration, including its effect on physical and mental development among children. There is strong evidence that Protein-Based Food intake have positive impact on weight gain, bone density, micronutrients repletion and cognition development among vulnerable populations. This review will shed the light on different intervention trials designed to tackle malnutrition by using animal source food provision, particularly, Milk and eggs.
\end{abstract}

Further work is required to clarify the purpose, delivery and outcomes of animal source food provision among vulnerable and poor individuals and communities.

Keywords: Protein-based food; Milk; Egg; Malnutrition

\section{Introduction}

The objectives of most of food intervention programs are optimizing the dietary intake of children and thereby enhancing their nutritional status, reducing the severity of illness and preventing death, diseases and disabilities [1].

Any food-based interventions must take into account these five concepts in order to make it successful; Acceptable, Feasible, Affordable, Sustainable and Safe (AFASS) [2]. It is very important to choose appropriate and cost-effective intervention strategies for the target population and this require pre knowledge about the nutritional status of this population, another important determinant one must take into account is social and cultural factors, food habits and taboos of the targeted community. Intervention program should have answers to the following questions what is fed, how food is prepared and given, who feeds the child, when food is fed (frequency and scheduling), and the feeding environment (where) [3]. Internationally agreed goals for the reduction of malnutrition and child mortality will be achieved only if families can receive the support and the assistance they need to adequately care for their children's nutritional needs, thus contributing to improved survival, growth, and development $[3,4]$.

In order to make food intervention programs more successful, strict inclusion and exclusion criteria must be implemented (e.g., only children who are malnourished or have difficult family situations, or continue to falter in growth are enrolled); the duration of food distributed per family or child might be limited, and may include extra food to provide enough for mothers and all children in the family. To attract mothers for other health services and facilities, such as immunizations, growth monitoring, deworming, and vitamin $\mathrm{A}$ supplementation and to encouraged caregivers to utilize these services monthly or quarterly food distributions have also been used . In some settings (e.g., day care centres or outpatient facilities), supervised daily feeding may be possible.

\section{Protein-Based Food (BPF) in the food intervention program}

Children and mothers of reproductive age comprise the highest risk and most vulnerable groups, particularly in low income and poor countries where nutrient deficiencies are prevalent due to poor dietary quantity and quality as a cost of hunger and deprivation $[5,6]$. The limited availability and accessibility of Protein-Based Food (BPF) at the household level, as well as the lack of knowledge about their benefits in human diet and health, result in a lower intake that contributes to poor diet quality [7]. In contrast, households spending more money on non-grain food such as ASF prevent their children from being stunted [8-10]. In affluent countries, strict vegetarian diets and fear of red meat dictated by spiritual and health beliefs result in suboptimal levels of macro and micronutrients. Such diet negatively affects the functioning of an increasing number of children $[7,11,12]$.

Consumption of ASF has been strongly associated with better growth, cognitive function, activity, pregnancy outcome, and morbidity in three parallel longitudinal observational studies in different ecologic and cultural parts of the world, namely, Egypt, Kenya, and Mexico [13-15]. Foods of domestic animal origin mainly contribute to diet [16]. Parents who fear to serve eggs and red meat to their children (to control the cholesterol level) are actually keeping them away from the densest sources of proteins, minerals, and vitamins; such sources could help promote growth, bridge the nutrient gap, strengthen the body, and improve the child's immunity to diseases [17].

Different studies have reported that ASF positively affects weight gain and contributes to a lean body mass. In a Kenyan study, school children who were given milk and meat for 21 months demonstrated improvement or increase in cognitive function, growth, physical activity and behaviour, and micronutrient status during the intervention [12].

In another study by Grillenberger et al. [18], milk and meat were provided to Kenyan school children for 23 months and achieved the following results. The meat, milk, and energy groups respectively gained

${ }^{*}$ Corresponding author: Ihab Naser, Program of Clinical Nutrition, Faculty of Pharmacy, Al Azhar University, Gaza Strip, Palestine, Tel: 00972598877027 ; E-mail: ihabnaser@yahoo.ca

Received January 25, 2016; Accepted February 22, 2016; Published February 29, 2016

Citation: Naser I (2016) Role of Protein-Based Food (PBF) in Combating Undernutrition; Milk and Eggs as an Example. J Nutr Disorders Ther 6: 184 doi:10.4172/2161- 0509.1000184

Copyright: (c) 2016 Naser I. This is an open-access article distributed under the terms of the Creative Commons Attribution License, which permits unrestricted use, distribution, and reproduction in any medium, provided the original author and source are credited. 
$0.33,0.19$, and $0.27 \mathrm{~cm}$ in mid-upper-arm circumference more than the children in the control group. In their mid-upper-arm muscle area, children who received the meat supplement gained $30 \%$ to $80 \%$ more than the other children, and those who received the milk supplement gained $40 \%$ more than children who did not receive any supplement. Wiley showed that younger children in the highest quartile of dairy intake had a higher body mass index (BMI) than those in the lowest two quartiles [19]. On the other hand, several studies did not support the association between ASF consumption and the physical growth of the child [20,21]. In an Indonesian study, milk consumption showed a significantly negative association with a child classified as underweight or stunted, but not with wasted children; meanwhile, the consumption of meat/poultry and eggs revealed no significant impact on all the $\mathrm{z}$ scores [22].

\section{Milk}

Milk is an important part of the human diet. Different types of milk include varying nutrients. Milk contains carbohydrates, protein, fat, minerals, and vitamins; thus, it is also considered as a complete diet. Each person is advised to consume a certain amount of milk to meet his/her nutritional needs. Milk and dairy products foster the growth of children, reduce the risk of faltering growth, as well as provide a base for strong and healthy bones. Both young children and adolescents need to fulfil their milk consumption recommendations [23]. In comparison, dairy products provide an ideal source of calcium, which is a central element for building strong and dense bones. New Zealand children with a history of avoidance to cow's milk were shorter than those without [24]. Young children and especially teenagers need to eat foods that are good sources of calcium for building healthy bones throughout life [25].

Calcium, including calcium from milk, has been associated with bone mineral accretion in children. In Hong Kong, 9- and 10-yearold children randomized to receive milk powder equivalent to 1,300 $\mathrm{mg} /$ day of calcium for 18 months had a significantly greater increase in total hip and spine bone mineral density (BMD) compared with controls, while those randomized to receive $650 \mathrm{mg} /$ day of calcium had a significantly greater increase in whole body BMD compared with controls [26].

Linoleic acid (LA; n-6) and a-linolenic acid (ALA; n-3) are polyunsaturated fatty acids (PUFAs) and precursors for endogenous synthesis of long-chain polyunsaturated fatty acids (LCPUFAs). The LA:ALA ratio of cow's milk is favourable and may actually facilitate tissue docosahexaenoic acid (DHA; n-3) synthesis [27]. One study comparing breast milk, formula, and cow's milk fed to full-term infants found the highest levels of DHA in the breastfed group followed by cow's milk group and lastly the milk formula group [28].

In addition to macro- and micronutrients, an important component of cow's milk is the insulin-like growth factor (IGF) which stimulates growth factors. IGF-1 is the most abundant in bone and promotes normal bone and tissue growth and development by increasing uptake of amino acids, which are integrated into new proteins in bone tissue [29].

There is reasonable evidence that milk consumption positively related with circulating concentrations of IGF-1. A significant increase in serum IGF-1 was observed in 82 British girls aged 12 years consuming 1 pint $(568 \mathrm{~mL}$ ) of milk daily for 18 months after adjustment for pubertal status [20], and in 24 Danish boys aged 8 years consuming $1,500 \mathrm{~mL}$ of milk daily for 1 week [30]. IGF-1 was positively associated with milk or dairy intake in 521 British children 7 and 8 years of age [31] and in
90 Danish children aged 2.5 years [32], but not in 105 Danish children aged 9 months and subsequently aged 10 years [33]. Potential factors in milk that may stimulate IGFs, including IGF-1 and insulin, are casein, branched-chain amino acids, calcium, and zinc [34].

Milk could be consumed either as a drink or in the form of milkderivatives such as dairy products. Table 1 illustrates the nutritional value of $100 \mathrm{~g}$, one cup, and one school milk carton for one serving. The U.S. Department of Agriculture Food Guide Pyramid recommends two to three servings per day from the milk, cheese, and yogurt group, primarily to promote adequate calcium intake for the prevention of osteoporosis during old age (USDA-Agriculture Research Services) (Table 1).

A total of 83 lactating Zairian mothers suffering from protein malnutrition were provided with cow milk for two months. Milk supplements provide $500 \mathrm{kcal}(2093 \mathrm{~kJ})$ and $18 \mathrm{~g}$ of protein a day. The mother's nutritional status significantly improved after two months of receiving the milk supplements. According to the mothers' nutritional status, the initial and changed milk output showed no significant difference. Breast-fed infants indicated a significant improvement of their mean serum albumin concentration, but their growth was similar to the mean growth of children of the same age [35].

Various studies have suggested that dairy proteins positively give impact on the vulnerable populations. Hoppe et al. examined the evidence on the effects of adding whey or skimmed milk powder to fortified blended foods (FBF) used for malnourished infants and young children or people living with HIV [36]. Adding whey or skimmed milk powder to FBF improves the protein quality and allows for a reduced total amount of protein intake, which could have potential metabolic advantages. This addition also allows for a reduced soy and cereal content, thereby a reduction in potential anti-nutrients. Adding milk could improve weight gain, linear growth, and recovery from malnutrition, but this result requires further studies [36].

Berkey confirmed the positive relationship between milk consumption and weight gain. Children who drank over three glasses of milk a day gained more in BMI than those who drank $1-2$ or $0-0.5$ glasses of milk a day. Drinking large amounts of milk may likewise provide excess energy to some children [37]. In an investigation of the consumption frequency of milk, cheese, yogurt, dietary protein, and dietary fat on subsequent growth, pre-menarcheal girls who drank over three servings of milk per day indicated larger growth the following year than girls who consumed less than one serving per day [38].

A school-based trial of milk intervention in Chinese girls resulted in body weight improvements and significantly greater linear growth over two years [39]. A longitudinal study of 92 Japanese children

\begin{tabular}{|c|c|c|c|}
\hline Measure Description & 100 Grams & 1 cup & 1 carton \\
\hline Servings & 1 & 1 & 1 \\
\hline Servings Weight & $100 \mathrm{~g}$ & $244 \mathrm{~g}$ & $244 \mathrm{~g}$ \\
\hline Water (g) & 88.32 & 215.5 & 215.5 \\
\hline Energy (kcal) & 60 & 146 & 146 \\
\hline Protein (g) & 3.22 & 7.86 & 7.86 \\
\hline Fat, total (g) & 3.25 & 7.93 & 7.93 \\
\hline Carbohydrate (g) & 4.52 & 11.03 & 11.03 \\
\hline Sugars, total (g) & 5.26 & 12.83 & 12.83 \\
\hline Fiber, total dietary (g) & 0 & 0 & 0 \\
\hline Cholesterol (mg) & 10 & 24 & 24 \\
\hline
\end{tabular}

Source: USDA-Agriculture Research Services, 2002.

Table 1: Nutritional values of milk. 
indicated a greater linear growth and weight gain among children who drank more milk over a three-year period [40].

Numerous studies in literature discussed the association between milk consumption and bone density, but the association between height and the milk consumption remains under investigation. National Health and Nutrition Examination Survey 1999-2002 (NHANES) data indicated significant differences in the effects of milk consumption on height. After controlling for potential confounders, the results implied that adult height was positively associated with milk consumption at ages 5 to 12 years and 13 to 17 years. Milk consumption demonstrated no effect on the height of 5 to 11 years old children [41].

A Malaysian study measured the impact of the school milk program on the nutritional status of children. A significant reduction in the prevalence of protein-energy malnutrition was determined in terms of underweight ( $15.3 \%$ to $8.6 \%)$, stunting (16.3\% to $8.3 \%)$, and wasting $(2.6 \%$ to $1.7 \%)$ from the start of the school feeding program until two years later [42].

\section{Eggs}

Eggs have been considered as a powerhouse of nutrition due to their excellent profile as a nutrient-dense food containing a balanced source of essential amino and fatty acids, some minerals and vitamins $[43,44]$ as well as a number of functional defensive factors to protect against bacterial and viral infections. Moreover, eggs are recognized to contain substances with biological functions beyond basic nutrition [45].

Since ancient times, chicken eggs have been used as food by humans. Compared to eggs, no other single animal-based food is eaten by so many people all over the world, and none is served in a wide variety of ways. The popularity of eggs is justified not only because of the ease of production and numerous uses in cookery, but also because of their nutritive quality [46].

Of the three macronutrients essentials (proteins, fats, and carbohydrates), the egg is composed largely of the first two. Furthermore, the nutritive quality of an egg enhances the value of any food in which it is included as an ingredient; it's widely used in cookery for the purposes of leavening, thickening, binding, and emulsifying considerably improves the human diet [47].

Egg proteins are highly digestible, containing the most important essential amino acids in a profile that is similar to the ideal balance of amino acids needed by both men and women. Eggs are an excellent source of protein. A typical egg would contribute approximately $3 \%$ to $4 \%$ of an adult's average energy requirement and approximately $6.5 \mathrm{~g}$ of protein. The major albumen proteins are ovalbumin (54\%), ovotransferrin $(14 \%)$, ovomucoid (11\%), ovomucin $(3.5 \%)$, lysozyme (3.5\%), and globulins (8\%) [48]. Egg protein is of high biological value because it contains all the essential amino acids needed by the human body. Thus, eggs complement other food proteins of lower biological value by providing the amino acids that are deficient in those foods. Approximately $12.5 \%$ of the weight of an egg is protein, which both the yolk and the albumen contain. Although protein is more concentrated around the yolk, more protein could be found in the albumen [48]. Eggs likewise provide various minerals, some in significant amounts, and contain major vitamins. For example, a recent U.S. study indicated that eggs contributed $10 \%$ to $20 \%$ of the daily intake of folate as well as total saturated and polyunsaturated fat, and also $20 \%$ to $30 \%$ of the daily intake of vitamins A, E, and B12 [49].
Chicken eggs are the most commonly consumed and have around 21 functional uses. The nutritional values of eggs and their contribution to the diet are illustrated in Table 2 (USDA-Agricultural Research Service).

As a high protein food, eggs appear in a food group with beef, poultry, fish, legumes, as well as other animal and vegetable protein sources on the Food Guide Pyramid. Eggs are well recognized among consumers as a top source of protein [43]. A medium egg has an energy value of $78 \mathrm{kcal}$ ( $324 \mathrm{kj})$, and the consumption of one egg daily would contribute only approximately $3 \%$ of the average energy requirement of an adult man and $4 \%$ for an adult woman.

The association between egg consumption and the physical growth of children was reported when eggs were added to the diet of a test group of Iranian children following the instruction of the nutritional education program. The children in the experimental group who ate more eggs than the control group demonstrated a significant growth improvement [50].

The common belief about the connection between egg consumption and high blood cholesterol remains under investigation, and several studies have dissipated the fear of eating eggs. Egg consumption is negatively associated to the serum cholesterol levels in most individuals [49]. Moreover, latest research has suggested that eating whole eggs may actually result in a significant improvement in one's cholesterol level. Including eggs in the diet of overweight men consuming a carbohydrate-restricted diet indicated an increased plasma HDL (good cholesterol) [51]. Eating two eggs daily had no significant impact on the children's ratio of LDL:HDL, which remained the same. However, the size of their LDL cholesterol increased, which is a highly beneficial change because a larger LDL is much less atherogenic than smaller LDL subfractions [52].

A large population-based study conducted in the United States from 1988 to 1994 reported that subjects who ate ready-to-eat cereal (RTEC), cooked cereal, or quick breads for breakfast had significantly lower BMI compared to skippers as well as eaters of meat and eggs. The meat-and-eggs eaters had the highest daily energy intake and the highest BMI [53]. In another study, children (24 to 60 months) were fed either a high-protein diet with $15 \%$ of energy as protein (bread and egg for breakfast, rice and chicken curry for lunch and supper, and a special milk formulation with soy oil every two hours between the major meals) or a standard-protein diet with $7.5 \%$ energy as protein (bread and sugar for breakfast, rice and lentil for lunch and supper, and a milk-rice powder-based formula every two hours to provide $7.5 \%$ of energy as protein) for 21 days in a metabolic study ward. Children were followed up bi-weekly for six months. A total of 31 children in the high-protein group and 28 children in the standard-protein group completed six months' follow-up. The increase in height was $5.3(1.0)$ $\mathrm{cm}$ vs. $4.1(1.1) \mathrm{cm}$ for high-protein and standard-protein groups, respectively, whereas the increase in body weight was 1.39 (0.58) and

\begin{tabular}{|c|c|c|c|}
\hline \multicolumn{2}{|c|}{ Constituent of Egg } & Amount per Egg & Amount per 100g \\
\hline Weight $^{2}$ & & 51.6 & 100.00 \\
\hline Water $^{2}$ & G & 38.8 & 75.1 \\
\hline Energy & joules/calories & $324 / 78$ & $627 / 151$ \\
\hline Protein & G & 6.5 & 12.5 \\
\hline Carbohydrate & G & Trace & Trace \\
\hline Fat & G & 5.8 & 11.2 \\
\hline
\end{tabular}

Source: USDA-Agricultural Research Service, 2002

Table 2: Nutritional values of egg without its shell. 
Citation: Naser I (2016) Role of Protein-Based Food (PBF) in Combating Undernutrition; Milk and Eggs as an Example. J Nutr Disorders Ther 6: 184. doi:10.4172/2161- 0509.1000184

1.29 (0.72) $\mathrm{kg}$ for children fed with high-protein and standard-protein meals, respectively. After six months, the proportion of children who were severely stunted decreased from $45 \%$ to $29 \%$ in the high-protein group compared to $50 \%$ to $46 \%$ in the standard-protein group [54].

Eggs have considerable amount of vitamin D (15\% Daily Value). The action of vitamin $\mathrm{D}$ is not limited to the absorption and deposition of bone salts, but that the vitamin has a more widespread effect on organic tissue metabolism, of which increased growth [55].

\section{Conclusion}

When choosing a suitable nutrition intervention strategy to address malnutrition, it is important to note that functional deficits may not be alleviated by the provision of single macro or micronutrients. Although the supplementation with milk and eggs did not bring about all the expected effects, several study findings indicate that nutrients contained in high amounts and in a bio-available form in animal source foods are beneficial for growth.

It is concluded that, animal source food is a viable food-based approach to combat malnutrition.

Therefore, is recommended to continue and strengthen the promotion of consuming a diverse diet that includes animal source food in supporting the growth of young children.

\section{References}

1. Barrett CB, Bruce LG, Gordon CR (2002) Chapter 40 Food security and food assistance programs. In: Handbook of Agricultural Economics (2ndedtn) Elsevier 2103-2190.

2. IFE Core Group: Infant and Young Child Feeding in Emergencies (2007) In Edited by Infant and Young Child Feeding in Emergencies. Oxford UK.

3. Pelto G, Levitt E, Thairu L (2003) Improving feeding practices: current patterns, common constraints, and the design of interventions. Special Issue Based on a World Health Organization Expert Consultation on Complementary Feeding 24: 45 .

4. UNICEF: Nutrition Essentials (1999) A Guide for health Managers. WHO, UNICEF, BASICS.

5. Gavrilovic M, Harper C, Jones N, Marcus R, Pereznieto P (2009) Impact of the Economic Crisis and Food and Fuel Price Volatility on Children and Women in Kazakhstan. Report for UNICEF Kazakhstan Office Overseas Development Institute: London.

6. Stein AJ, Qaim M (2007) The human and economic cost of hidden hunger Food Nutr Bull 28: 125-134.

7. Murphy SP, Allen LH (2003) Nutritional importance of animal source foods. J Nutr 133: 3932S-3935S.

8. Sari M, de Pee S, Bloem MW, Sun K, Thorne-Lyman AL, et al. (2010) Higher Household Expenditure on Animal-Source and Nongrain Foods Lowers the Risk of Stunting among Children 0 -59 Months Old in Indonesia. Implications of Rising Food Prices 140: 195S-200S.

9. Darapheak C, Takano T, Kizuki M, Nakamura K, Seino K (2013) Consumption of animal source foods and dietary diversity reduce stunting in children in Cambodia. Int Arch Med 6: 29.

10. Muslimatun S, Wiradnyani L (2016) Dietary diversity, animal source food consumption and linear growth among children aged 1-5 years in Bandung Indonesia: a longitudinal observational study. The British journal of nutrition 2016: $1-9$

11. Dagnelie PC, van Staveren WA, Hautvast JG (1991) Stunting and nutrient deficiencies in children on alternative diets. Acta Paediatr Scand Suppl 374 111-118.

12. Neumann CG, Bwibo NO, Murphy SP, Sigman M, Whaley S, et al. (2003) Animal source foods improve dietary quality, micronutrient status, growth and cognitive function in Kenyan school children: background, study design and baseline findings. J Nutr 133: 3941S-3949S.
13. Allen L, Backstrand J, Chavez A, Pelto G (1992) People cannot live by tortillas alone: The results of the Mexico nutrition CRSP. Storrs, CT: University of Connecticut.

14. Kirksey A, Harrison G, Galal O, McCabe G, Wachs T, et al. (1992) The Human Cost of Moderate Malnutrition in an Egyptian Village, Final Report Phase II. Nutrition CRSP Purdue University, Lafayette, Indiana.

15. Neumann C, Bwibo N, Sigman M (1992) Final Report Phase II: Functional Implications of Malnutrition, Kenya. Nutrition CRSP University of California, Los Angeles, CA.

16. Givens DI, Shingfield KJ (2004) Foods derived from animals: the impact of animal nutrition on their nutritive value and ability to sustain long-term health. Nutrition Bulletin 29: 325-332.

17. Roberts SB, Heyman MB (2000) How To Feed Babies and Toddlers in the 21st Century. Zero to Three 21: 24-28.

18. Grillenberger M, Neumann CG, Murphy SP, Bwibo NO, van't Veer P, et al (2003) Food supplements have a positive impact on weight gain and the addition of animal source foods increases lean body mass of Kenyan schoolchildren. $J$ Nutr 133: 3957S-3964S.

19. Wiley AS (2010) Dairy and milk consumption and child growth: Is BMI involved? An analysis of NHANES 1999-2004. Am J Hum Biol 22: 517-525.

20. Cadogan J, Eastell R, Jones N, Barker ME (1997) Milk intake and bone minera acquisition in adolescent girls: randomised, controlled intervention trial. BMJ 315: $1255-1260$

21. Cook J, Irwig LM, Chinn S, Altman DG, Florey CD (1979) The influence of availability of free school milk on the height of children in England and Scotland. J Epidemiol Community Health 33: 171-176.

22. lannotti L, Barron M, Roy D (2008) Animal Source Food Consumption and Nutrition Among Young Children in Indonesia: Preliminary Analysis for Assessing the Impact of HPAI on Nutrition. DFID Pro-poor HPAI Risk Reduction Strategies Project Research Report.

23. Kim S, Douthitt R (2003) Mothers' Health Awareness and Its Impact on Children's Dairy Product Intakes. Family and Consumer Sciences Research Journal 31: 272-296

24. Black RE, Williams SM, Jones IE, Goulding A (2002) Children who avoid drinking cow milk have low dietary calcium intakes and poor bone health. Am J Clin Nutr 76: 675-680.

25. USDA/ERS (2010) Women, Infant and Child Program. In: Women, Infant and Child Program: November 2010 estimate for five years 2010. Department of Public Health.

6. Lau EM, Lynn H, Chan YH, Lau W, Woo J (2004) Benefits of milk powder supplementation on bone accretion in Chinese children. Osteoporos Int 15 654-658.

27. Michaelsen KF, Hoppe C, Lauritzen L, Molgaard C (2007) Whole cow's milk: why, what and when? Nestle Nutr Workshop Ser Pediatr Program 60: 201-216.

28. Courage ML, McCloy UR, Herzberg GR, Andrews WL, Simmons BS, et al (1998) Visual acuity development and fatty acid composition of erythrocytes in full-term infants fed breast milk, commercial formula, or evaporated milk. J Dev Behav Pediatr 19: 9-17.

29. Cameron N, Bogin B (2012) Human growth and development: Academic Press

30. Hoppe C, Mølgaard C, Juul A, Michaelsen KF (2004) High intakes of skimmed milk, but not meat, increase serum IGF-I and IGFBP-3 in eight-year-old boys. Eur J Clin Nutr 58: 1211-1216.

31. Rogers I, Emmett P, Gunnell D, Dunger D, Holly J; ALSPAC Study Tteam (2006) Milk as a food for growth? The insulin-like growth factors link. Public Health Nutr 9: 359-368.

32. Hoppe C, Udam TR, Lauritzen L, Mølgaard C, Juul A, et al. (2004) Animal protein intake, serum insulin-like growth factor I, and growth in healthy 2.5 -y-old Danish children. The American journal of clinical nutrition 80: 447-452.

33. Hoppe C, Mølgaard C, Thomsen BL, Juul A, Michaelsen KF (2004) Protein intake at 9 mo of age is associated with body size but not with body fat in 10-y-old Danish children. Am J Clin Nutr 79: 494-501.

34. Hoppe C, Mølgaard C, Michaelsen KF (2006) Cow's milk and linear growth in industrialized and developing countries. Annu Rev Nutr 26: 131-173.

35. Donnen P, Brasseur D, Dramaix M, Assimbo V, Hennart P (1997) Effects of 
Citation: Naser I (2016) Role of Protein-Based Food (PBF) in Combating Undernutrition; Milk and Eggs as an Example. J Nutr Disorders Ther 6: 184. doi:10.4172/2161-0509.1000184

cow's milk supplementation on milk output of protein deficient lactating mothers and on their infants' energy and protein status. Trop Med Int Health 2: 38-46.

36. Hoppe C, Andersen GS, Jacobsen S, Mølgaard C, Friis H, et al. (2008) The use of whey or skimmed milk powder in fortified blended foods for vulnerable groups. J Nutr 138: 145S-161S

37. Berkey CS, Rockett HR, Willett WC, Colditz GA (2005) Milk, dairy fat, dietary calcium, and weight gain: a longitudinal study of adolescents. Arch Pediatr Adolesc Med 159: 543-550.

38. Berkey CS, Colditz GA, Rockett HRH, Frazier AL, Willett WC (2009) Dairy consumption and female height growth: prospective cohort study. Cancer Epidemiology Biomarkers \& Prevention 18: 1881-1887.

39. Du X, Zhu K, Trube A, Zhang Q, Ma G, et al. (2004) School-milk intervention trial enhances growth and bone mineral accretion in Chinese girls aged 10-12 years in Beijing. Br J Nutr 92: 159-168.

40. Okada T (2004) Effect of cow milk consumption on longitudinal height gain in children. Am J Clin Nutr 80: 1088-1089.

41. Wiley AS (2005) Does milk make children grow? Relationships between milk consumption and height in NHANES 1999-2002. Am J Hum Biol 17: 425-441.

42. Chen ST (1989) Impact of a school milk programme on the nutritional status of school children. Asia Pac J Public Health 3: 19-25.

43. Applegate $E$ (2000) Introduction: nutritional and functional roles of eggs in the diet. J Am Coll Nutr 19: 495S-498S.

44. Surai PF, Sparks NHC (2001) Designer eggs: from improvement of egg composition to functional food. Trends in Food Science \& Technology 12: 7-16.

45. Kovacs-Nolan J, Phillips M, Mine Y (2005) Advances in the value of eggs and egg components for human health. J Agric Food Chem 53: 8421-8431.
46. Stadelman W, Cotterill O (1995) Egg science and technology: CRC

47. Stadelman WJ (1999) The incredibly functional egg. Poult Sci 78: 807-811.

48. Li-Chan E, Powrie W, Nakai S (1995) The chemistry of eggs and egg products Egg science and technology (4thedn) Food product Press New York, London.

49. Song WO, Kerver JM (2000) Nutritional contribution of eggs to American diets. J Am Coll Nutr 19: 556S-562S.

50. Salehi M, Kimiagar SM, Shahbazi M, Mehrabi Y, Kolahi A (2004) Assessing the impact of nutrition education on growth indices of Iranian nomadic children an application of a modified beliefs, attitudes, subjective-norms and enablingfactors model. Br J Nutr 91: 779-787.

51. Mutungi G, Ratliff J, Puglisi M, Torres-Gonzalez M, Vaishnav U, et al. (2008) Dietary cholesterol from eggs increases plasma HDL cholesterol in overweight men consuming a carbohydrate-restricted diet. J Nutr 138: 272-276.

52. Ballesteros MN, Cabrera RM, del Socorro Saucedo M, Fernandez ML (2004) Dietary cholesterol does not increase biomarkers for chronic disease in a pediatric population from northern Mexico. The American journal of clinical nutrition 80: 855-861.

53. Cho S, Dietrich M, Brown CJP Clark CA, Block G (2003) The Effect of Breakfast Type on Total Daily Energy Intake and Body Mass Index: Results from the Third National Health and Nutrition Examination Survey (NHANES III) J Am Coll Nutr 22: 296-302.

54. Kabir I, Rahman MM, Haider R, Mazumder RN, Khaled MA et al. (1998) Increased height gain of children fed a high-protein diet during convalescence from shigellosis: a six-month follow-Up study. J Nutr 128: 1688-1691.

55. Steenbock H, Herting DC (1955) Vitamin D and growth. J Nutr 57: 449-468. 